\title{
Stable isotope ratio analysis of traditional and nontraditional elements in plant science - current status and future trends
}

\author{
KRISTIAN HOLST LAURSEN AND MARIA MONRAD \\ RIECKMANN
}

University of Copenhagen

Presenting Author: holst@plen.ku.dk

Plants require 17 elements of the periodic table in order to complete a life cycle. Besides $\mathrm{H} / \mathrm{C} / \mathrm{O}$, these are denoted as the macronutrients: $\mathrm{N} / \mathrm{Mg} / \mathrm{P} / \mathrm{S} / \mathrm{K} / \mathrm{Ca}$ and the micronutrients: $\mathrm{B} / \mathrm{Cl} / \mathrm{Mn} / \mathrm{Fe} / \mathrm{Ni} / \mathrm{Cu} / \mathrm{Zn} / \mathrm{Mo}$. Most of these elements are acquired as inorganic ions from the soil solution and are subsequently translocated in plant tissue and utilized in a plethora of biological and biochemical functions. All essential plant nutrients, except $\mathrm{P}$ and $\mathrm{Mn}$ exist as two or more stable isotopes. The light isotopes are most often present in highest abundance in plant tissue, but isotopic fractionation in biological and biochemical processes generate unique isotopic signatures of plants that reflect nutrient availability, acquisition and utilization.

Much efforts have been put into understanding nutrient utilization and the functional roles of nutrients in plant metabolism. Mass spectrometry has played a major role in this work by, for example, multi-element analysis and stable isotope enrichments. Compared to enrichment studies, measurement of changes in the natural abundance of stable isotopes of plant nutrients is a much more readily applicable and versatile approach. However, stable isotope ratio analysis at the natural abundance level has for decades been restricted to a very limited number of plant nutrients due to analytical limitations. The majority of plant studies using stable isotope ratio analysis have thus so far focused on the light mass elements $\mathrm{H} / \mathrm{C} / \mathrm{N} / \mathrm{O} / \mathrm{S}$ that are easily converted into simple gases. Analytical developments, in especially geochemistry, now allow stable isotope ratio analysis of several other essential plant nutrients at the natural abundance level including: $\mathrm{B} / \mathrm{Mg} / \mathrm{Cl} / \mathrm{K} / \mathrm{Ca} / \mathrm{Fe} / \mathrm{Ni} / \mathrm{Cu} / \mathrm{Zn} / \mathrm{Mo}$. In addition, compound-specific isotope ratio analysis represents a promising new analytical development that also enables tracing of mono-isotopic plant nutrients such as phosphorus in the form of phosphate via oxygen isotope analysis.

At the conference, an overview of climatic, edaphic, biological and biochemical factors controlling stable isotope signatures of plants, and common pitfalls in sampling, sample preparation, analysis and data interpretation will be presented. Emerging analytical approaches, such as compound-specific stable isotope ratio analysis, isotope ratio analysis of non-traditional elements and its applicability in plant science will be discussed. 